
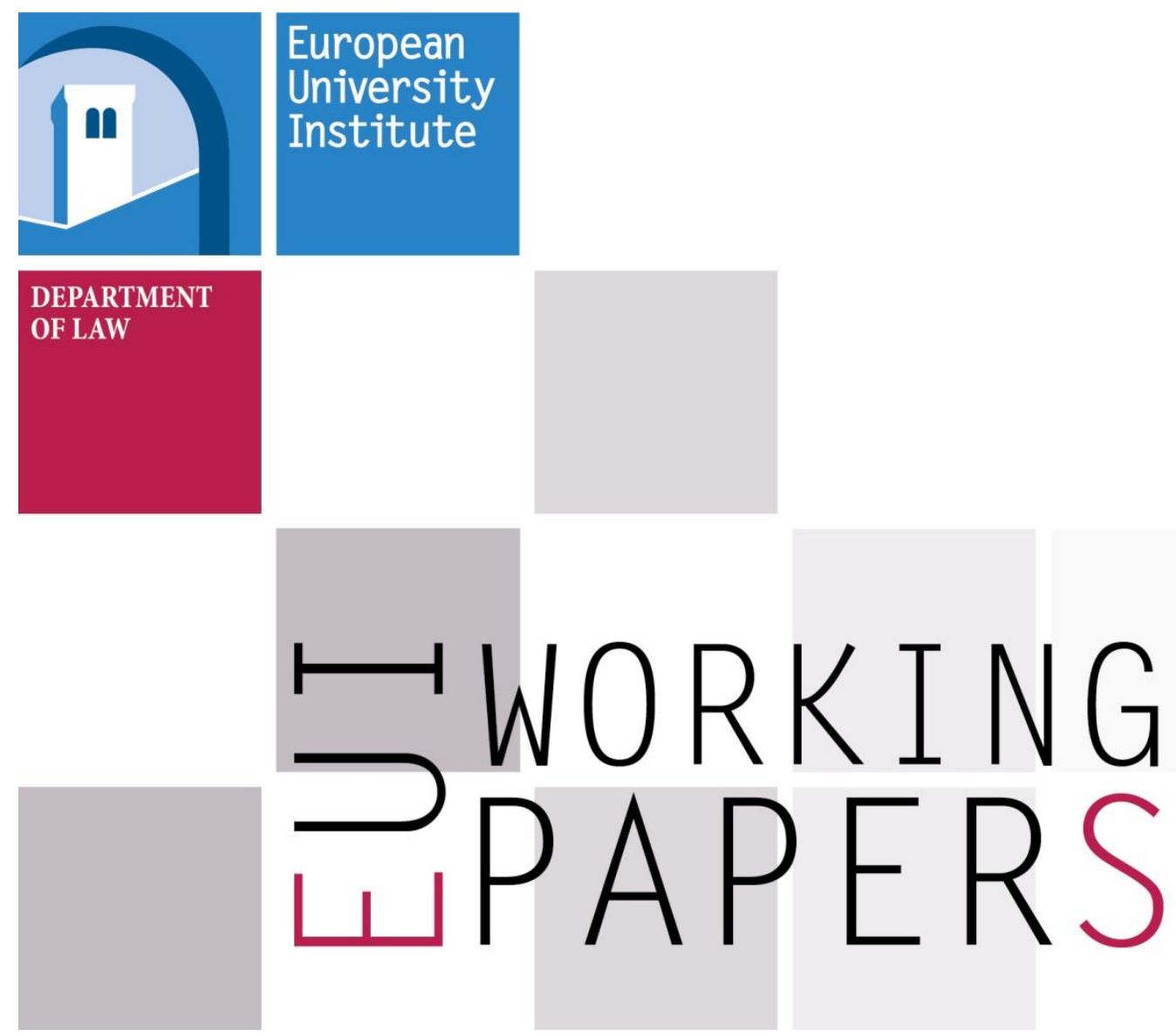

LAW 2018/03

Department of Law

Dead man walking: Current European interest in the ordoliberal tradition

Josef Hien \& Christian Joerges 

European University Institute Department of Law

\section{DEAD MaN WALKING: CURRENT EUROPEAN INTEREST IN THE ORDOLIBERAL TRADITION}

Josef Hien \& Christian Joerges

EUI Working Paper LAW 2018/03 
This text may be downloaded for personal research purposes only. Any additional reproduction for other purposes, whether in hard copy or electronically, requires the consent of the authors. If cited or quoted, reference should be made to the full name of the authors, the title, the working paper or other series, the year, and the publisher.

ISSN 1725-6739

(C) Josef Hien \& Christian Joerges, 2018

Printed in Italy

European University Institute

Badia Fiesolana

I-50014 San Domenico di Fiesole (FI)

Italy

www.eui.eu

cadmus.eui.eu 


\begin{abstract}
Ordoliberalism became during the years of the financial crisis the target of a European-wide critical campaign. This school of thought is widely perceived as the ideational source of Germany's crisis politics which has even led to an "ordoliberalisation of Europe". The essay questions the validity of such assessments. It focuses on two aspects which are widely neglected in current debates. One is the importance of law in the ordoliberal vision of the ordering of economy and society. The second is its cultural and religious background in particular in German Protestantism. The influence of the ordoliberal school on European law, so the essay argues, is overrated in all stages of the integration project. AngloAmerican neoliberalism rather than German Ordoliberalism was in the ideational driver seat since the 1980s. In the responses to the financial crisis the ordoliberal commitment to the rule of law gave way to discretionary emergency measures. While the foundational synthesis of economic and legal concepts became indefensible, the cultural underpinnings of the ordoliberal tradition survived and developed a life of their own in particular in German political discourses.
\end{abstract}

\title{
Keywords
}

ordoliberalism, economic cultures, financial crisis, Ordnungspolitik, crisis law 
Author contact details:

\section{Josef Hien}

Post doctoral fellow REScEU Team

University of Milan

and Berlin Social Science Center (WZB)

JosefHien@googlemail.com

\section{Christian Joerges}

Professor of Law and Society,

Hertie School of Governance, Berlin

Co-Director

Centre of European Law and Politics

University of Bremen

Joerges@hertie-school.org 


\section{Table of contents}

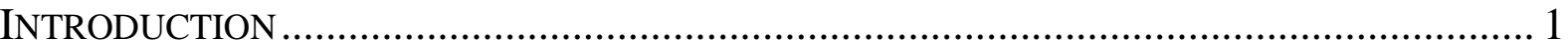

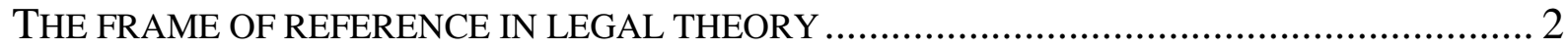

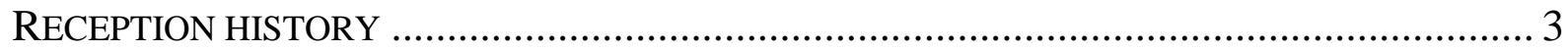

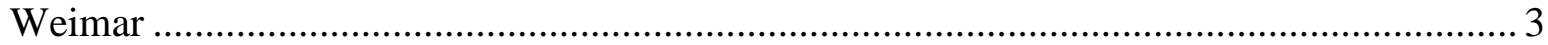

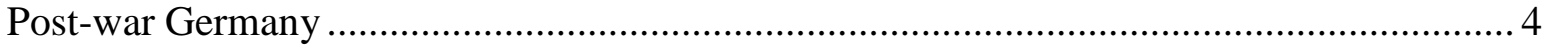

CULTURAL UNDERPINNINGS AND CONTEXTS OF THE POLITICAL AGENDA OF ORDOLIBERALISM SINCE THE WEIMAR REPUBLIC ......................................... 6

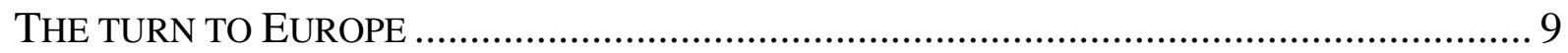

The Formative Phase of "Constitutionalisation" of the EEC Treaty ................................... 9

Von Hayek's and Mestmäcker's “Neo-ordoliberalism".................................................. 11

The Economic and Monetary Union (EMU) in the Maastricht Treaty as a Pyrrhic

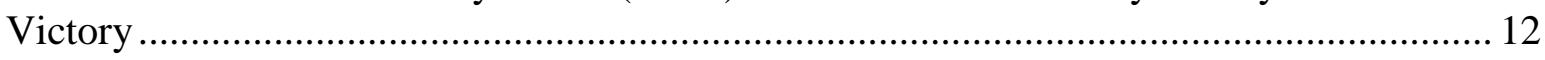

CRISIS POLICY: AN “ORDOLIBERALISATION OF EUROPE” OR THE FAILURE

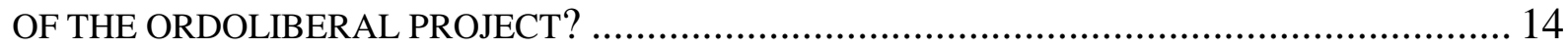

THE DISINTEGRATION OF ORDOLIBERALISM IN ECONOMIC SCIENCE .......................... 17

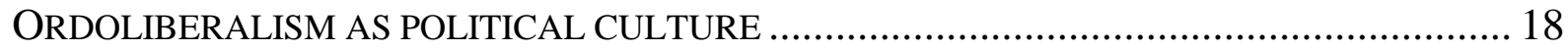

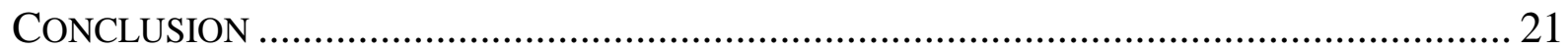





\section{Introduction}

Ordoliberalism is casting its shadow across Europe. Known to just a handful of dyed-in-the-wool experts outside the German-speaking world prior to the euro crisis, this theoretical tradition of social philosophy has made quite a name for itself over the past seven years. Weighty contributions in the press $^{1}$ and academic publications ${ }^{2}$ view ordoliberalism as an economic policy concept that is said to have guided the German government during the debt crisis. The influence of this policy, they claim, had brought about an "ordoliberalisation of Europe". Contributions echoing this criticism are relatively rare in Germany. ${ }^{3}$ This finding is the starting point of our deliberations: criticism of ordoliberalism is above all a criticism of German crisis policy.

Recent interest in ordoliberalism has been focused closely on its ideas regarding economic policy. Yet people forget the extent to which the founding fathers insisted on interdisciplinarity and perceived the economic order as a legal order. Besides the fact that ordoliberalism was originally anchored in legal concepts, we will go into a second foundational element which is also left largely unconsidered in the current debate, namely the fact that the values underlying ordoliberal theory and constituting its sociological core are heavily influenced by Protestantism.

We believe the direct impact ordoliberalism has in shaping German's policy toward Europe is overestimated. The influence of this school on forming the project of integration was minor, even in the formative 1950s and 1960s. Its theoretical power and practical relevance have been declining since the 1960s. Its backing in the legal sciences became weaker and weaker given the impact of American "economic analysis of law". ${ }^{4}$ Gradually, economists close to the ordoliberal tradition have largely

${ }^{1}$ The Guardian, "Let us Introduce you to 'Ordoliberalism”, 2 March 2012; The Financial Times, “The Wacky Economics of Germany's Parallel Universe", 16 November 2014; The Economist, "German Ordoliberalism has had a Big Influence on Policymaking during the Euro Crisis”, 9 May 2015.

2 S. Cesarotto and A. Stirati, "Germany and the European and Global Crises", (2010) 39 Journal of Political Economy, 56-86; V. Berghahn and B. Young, "Reflections on Werner Bonefeld's 'Freedom and the Strong State: On German Ordoliberalism' and the Continuing Importance of the Ideas of Ordoliberalism to Understand Germany's (Contested) Role in Resolving the Eurozone Crisis", (2013) 18 New Political Economy, 768-78; M. Blyth, Austerity: The History of a Dangerous Idea, (Oxford University Press, 2013), S. 141; S. Bulmer and W.E. Paterson, "Germany as the EU'sReluctant Hegemon? Of Economic Strength and Political Constraints", (2013) 20 Journal of European Public Policy, 1387-1405; P. Dardot and C. Laval, The New Way of the World: On Neoliberal Society, (Verso Books, 2013); Gerhard Schnyder and Mathias M. Siems, "The 'Ordoliberal' Variety of Neoliberalism", in: Suzanne J. Konzelmann and Marc Fovargue-Davies (eds), Banking Systems in the Crisis; The Faces of Liberal Capitalism, (Routledge, 2013), 250-268; S. Bulmer, "Germany and the Eurozone Crisis: Between Hegemony and Domestic Politics", (2014) 37 West European Politics, 1244-63; T. Harjunienu and M. Ojala, "Mediating 'the German Ideology'? Ordoliberalism and its Alternatives in the Press Coverage of the Eurozone Crisis", (2014) 24 Journal of Contemporary European Studies, 414-430; F. Denord, R. Knaebel and P. Rimbert, "L'ordolibéralisme allemand, cage de fer pour le Vieux Continent", Le Monde diplomatique, August 2015; R. Hillebrand, "Germany and its Eurozone Crisis Policy: The Impact of the Country's Ordoliberal Heritage", (2015) 33 German Politics \& Society, 6-24; A. Lechevalier, "Eucken under the Pillow: The Ordoliberal Imprint on Social Europe", in: A. Lechevallier and J. Wielgohs (eds), Social Europe: A Dead End: What the Eurozone Crisis is Doing to Europe's Social Dimension, (DJØF Publishing, 2015); P. Nedergaard and H. Snaith, ““As I Drifted on a River I could not Control': The Unintended Ordoliberal Consequences of the Eurozone Crisis”, (2015) 53 Journal of Common Market Studies, 10941109; D. Schäfer, "A Banking Union of Ideas? The Impact of Ordoliberalism and the Vicious Circle on the EU Banking Union", (2016) 54 Journal of Common Market Studies, 961-980; J. Oksala, “Ordoliberalism as Governmentality”, in: T. Biebricher and F.S. Vogelmann (eds), The Birth of Austerity: German Ordoliberalism and Contemporary Neoliberalism, (Rowman \& Littlefield, 2017).

${ }^{3}$ S. Dullien and U. Guérot, "The Long Shadow of Ordoliberalism: Germany's Approach to the Euro Crisis", (2012) 22 European Council on Foreign Relations Policy Brief; T. Biebricher, "Europe and the Political Philosophy of Neoliberalism", (2013) 12 Contemporary Political Theory, 338-375; idem, "Neoliberalism and Law: The Case of the Constitutional Balanced-Budget Amendment", (2016) 17 German Law Journal, 835-856.

${ }^{4}$ H.-D. Assmann, Ch. Kirchner and E. Schanze, Ökonomische Analyse des Rechts, (Athenäum, 1972) gave important signals. 
aligned their positions with those of Anglo-Saxon neoclassical economics - ordoliberalism has fallen victim to overlying American influences on German economics. It is telling that during the euro crisis, there were no genuinely ordoliberal contributions by economists or legal scholars that supported Germany's crisis policy. Opinion pieces by German economists institutionally linked to ordoliberalism (through the Walter Eucken Institut, the Stiftung Marktwirtschaft, the Kronberger Kreis) take up publicchoice theories and the new institutional economics in which the original interdependencies between law, economics, and the constitution have faded away.

Nonetheless, we find ordoliberal traditions having indirect influence. This influence is exerted based on its sociological core: the underlying Protestant cultural values that originally constituted the foundation for ordoliberalism formed and still forms German politicians' discourse on the crisis. Ordoliberalism thus continues to be influential in German politics thanks to its cultural foundations; politicians use ordoliberal references symbolically to indicate certain political mindsets and orientations.

In the following sections, we first outline the framework of ordoliberalism in legal theory (2.), trace the history of its early reception (3.), and provide evidence for its cultural anchoring in Protestantism (4.). This is followed by an analysis of how ordoliberal theoreticians influenced the establishment of European institutions in the early phases of integration (5.). We then turn to European crisis policy (6.) and consider the academic decline of ordoliberalism (7). We have devoted a section to how German politicians resorted to ordoliberal topoi in their discourse (8) and conclude with a summary (9).

\section{The Frame of reference in legal theory}

In contrast to the countless current contributions to ordoliberalism, law will assume a key role in our reconstruction of the history of its reception. We have compelling reasons for this. Of the three who signed the ordoliberal founding document of 1936, ${ }^{5}$ two were jurists (Franz Böhm and Hans GroßmannDoerth), and the third (Walter Eucken) was an economist who considered law and economics to be interdependent orders. Michel Foucault, who in 1979 discussed ordoliberalism in five of his 12 lectures on la naissance de la biopolitique, identified the constitutive significance of the law, which the current criticism scarcely acknowledges, very precisely: "The juridical gives form to the economic, and the economic would not be what it is without the juridical." ${ }^{\prime 6}$ Legal rules and economic activity are mutually dependent. "[T]he state can make legal interventions in the economic order only if these legal interventions take the form solely of the introduction of formal principles."

In the early Federal Republic, it was primarily jurists who communicated the practical-political influence of ordoliberal thought. Their most important place of activity was not Freiburg, however, but Frankfurt. That was where the later President of the Commission Walter Hallstein had been appointed professor in 1941 and had become president of the university in 1946; Ernst-Joachim Mestmäcker, who was to grow into the leadership role of the "second-generation" ordoliberals, completed his habilitation in 1958 under Franz Böhm, who had joined the faculty in 1946, as did Kurt Biedenkopf, who defended ordoliberal positions steadfastly as a scholar, policy consultant, and politician, in 1963. ${ }^{7}$ However, Böhm's chair of economic law was assumed in 1963 by a certain Rudolf Wiethölter, who wrote the most succinct analysis of ordoliberal legal theory and classifies its core characteristics, or proprium, as a social theory. As summarised concisely in Wiethölter's typical fashion: The "dominant motto," he writes, is

\footnotetext{
${ }^{5}$ F. Böhm, "Die außerstaatliche ('natürliche') Gesetzmäßigkeit des wettbewerblichen Wirtschaftsprozesses", in: W. Stützel, C. Watrin, H. Willgerodt and K. Hohmann (eds), Grundtexte zur Sozialen Marktwirtschaft: Zeugnisse aus zweihundert Jahren ordnungspolitischer Diskussion, (Fischer Verlag, [1936] 1981), 135-142.

${ }^{6}$ M. Foucault, Geschichte der Gouvernementalität II. Die Geburt der Biopolitik, (Suhrkamp Verlag, 2014), 163 \& 171.

${ }^{7}$ K.H. Biedenkopf, “Über das Verhältnis wirtschaftlicher Macht zum Privatrecht”, in: H. Coing et al. (eds), Festschrift zum 70. Geburtstag von Franz Böhm, (C.F. Müller, 1965); most recently, idem, Der Weg zum Euro. Stationen einer verpassten Chance, (Hertie School of Governance, 2012) with telling reservations against the introduction of the euro.
} 
"order (= 'reasonable assembly of the diverse to form a whole' - Eucken, taking on the scholastic concept of ordo). This 'order' is a legal order: 'Economic order is legal constitution' (Böhm). As a legal order, it is an order respecting and protecting "freedom" [...] core hypothesis on the normative proprium and impact of 'law': The economic order as an order of private law constituted in terms of competition policy develops material freedom and social equality of opportunity from private autonomy and the system of legal transactions through the fundamental ideas of private law which are functionalized in terms of competition law (freedom of contract, freedom to do business, freedom to own property)."8

According to Wiethölter, this was neither an economic theory ("theoretical economics based on a law of causality" or "economic policy designed to implement a particular programme") nor a legal theory as generally understood; rather, it was a "political theory of society" that "conceived of a "third way' beyond liberalism and socialism as a permanent and liberal order of peace". ${ }^{9}$ Wiethölter wrote this critical précis of ordoliberal legal theory at the time when the ordoliberal tradition was dominant in economic law in the Federal Republic and representatives of the school held leading positions in all the important consulting institutions.

However, as already mentioned above,${ }^{10}$ ordoliberalism has become less attractive since the 1970s. In the arguments related to the financial crisis, opinions committed to the conceptual foundations and the theoretical ambitions of ordoliberalism are hardly perceptible any more. We will return to this in more detail. ${ }^{11}$ To formulate our initial hypothesis more precisely even at this point: The "law of the crisis" with which Germany and Europe reacted to the financial crisis brought about a "delegalisation" of the EU. The numerous critics who wish to see an ordoliberal agenda at work in the crisis policy fail to recognise this circumstance. It is our opinion that the dramatic plight Europe found itself in was also due to the fact that the law - ordoliberal law just as well as any other law - falls short of legitimately formulating what comprises European governance.

\section{Reception History}

The long national and briefer European reception history of the ordoliberal theory was by no means only straightforward and successful. Although ordoliberalism was influential during some phases, resistance against it both in the Federal Republic and in Europe caused it to fail.

\section{Weimar}

In its beginnings in the early 1920s and 1930s, ordoliberalism constituted itself as an oppositional science: forward thinkers such as Eucken, Böhm, Rüstow, and Röpke opposed both laissez-faire liberalism and manifestations of power relationships typical of German organized capitalism. Alexander Rüstow's 1932 polemic against "paleoliberalism" speaks volumes. ${ }^{12}$ Walter Eucken's "Staatliche Strukturwandlungen und die Krise des Kapitalismus" ("Structural Transformations of the State and the

\footnotetext{
${ }^{8}$ R. Wiethölter, "Wirtschaftsrecht”, in: A. Görlitz (ed), Handlexikon zur Rechtswissenschaft, (Ehrenwirth, 1972), 531-538, at $534 \mathrm{f}$.

${ }^{9}$ Ibid., 535.

${ }^{10}$ Section 1 with fn. 8 .

${ }^{11}$ Section 6.

${ }^{12}$ A. Rüstow, "Paläoliberalismus, Kollektivismus und Neoliberalismus in der Wirtschafts- und Sozialordnung", in: K. Forster (ed.), Christentum und Liberalismus - Studien und Berichte der Katholischen Akademie in Bayern, (1932); idem, "Interessenpolitik oder Staatspolitik?", (1932) 7 Der Deutsche Volkswirt, 169-172; idem, "Freie Wirtschaft - starker Staat", (1932) 187 Schriften des Vereins für Socialpolitik, 62-69.
} 
Crisis of Capitalism") ${ }^{13}$ had the same general thrust. Other advocates of the school, later renowned, contributed their thoughts at the same time or soon after. ${ }^{14}$ Franz Böhm's monograph on "Wettbewerb und Monopolkampf' ("Competition and Struggle against Monopolies"), which was published in 1933, was to become the foundation for a school of legal thought. ${ }^{15}$ The new liberalism distinguished itself from the historical school of economics and was firmly opposed to socialist ambitions. ${ }^{16}$ But it was not laissez-faire liberalism - above all, because the state was assigned the task of guaranteeing the competitive order of the economy. Wilhelm Röpke used the vexing oxymoron "liberal interventionism" to describe this function. ${ }^{17}$ The idea was in fact to replace the old "paleoliberal" night-watchman state with a "strong state".

The call for a strong state in particular provoked nefarious suspicions. We also view them as anticipating disapproval being seen today. They do not impact ordoliberalism. The no longer only "quantitatively", but now "qualitatively" strong state that Carl Schmitt and some of his contemporaries called for ${ }^{19}$ was to derive its political clout from discretionary opportunities for intervention that threw the shackles off the rule of law. Ordoliberalism's strong state was supposed to use its strength to shape a legal constitution in which a free and fair order of competition would develop. Its power to shape policy was intended to help contain economic power while binding itself to legal forms of action. This is how Carl Schmitt's strong state differs fundamentally from the ordoliberals' rule-bound Ordnungspolitik.

\section{Post-war Germany}

Ordoliberalism is one of the few traditions that National Socialism had not damaged permanently. The "strong state" just mentioned remained an ordoliberal desideratum in a sense well defined in economic and societal policy. Franz Böhm led the way in formulating this program more precisely ${ }^{20} \mathrm{He}$ saw the regulatory weakness of the Weimar Republic's democratic pluralism regarding the concentration of power in the economy as one cause for the National Socialists seizing power. After 1945, he emphasised that "the refined competitive economy" was compatible with democracy under the rule of law, in contrast to a "centrally planned economy", but also more compatible than a "mixed economic system". ${ }^{21}$

${ }^{13}$ W. Eucken, "Staatliche Strukturwandlungen und die Krisis des Kapitalismus", (1997) [1932] 48 ORDO: Jahrbuch für die Ordnung von Wirtschaft und Gesellschaft, 5-25.

${ }^{14}$ A. Müller-Armack, Entwicklungsgesetze des Kapitalismus. Ökonomische, geschichtstheoretische und soziologische Studien zur modernen Wirtschaftsverfassung, (Junker und Dünnhaupt, 1932. On Müller-Armack's life and work, cf. D. Haselbach, Autoritärer Liberalismus und Soziale Marktwirtschaft. Gesellschaft und Politik im Ordoliberalismus, (Nomos Verlag, 1991, $117 \mathrm{ff}$.

${ }^{15}$ F. Böhm, Wettbewerb und Monopolkampf; eine Untersuchung zur Frage des wirtschaftlichen Kampfrechts und zur Frage der rechtlichen Struktur der geltenden Wirtschaftsordnung, (Carl Heymanns Verlag, [1933] 1964).

${ }^{16}$ W. Abelshauser, Kulturkampf. Der deutsche Weg in die neue Wirtschaft und die amerikanische Herausforderung, (Kadmos, 2003), $158 \mathrm{ff}$.

17 W. Röpke, German Commercial Policy, (Longmans, Green and Company, 1934), 40 f; idem, Die Lehre von der Wirtschaft, (Springer, 1937); on Röpke, cf., M. Glasman, Unnecessary Suffering: Managing Market Utopia, (Verso Books, 1996), 52 ff.

${ }^{18}$ Rüstow, speaking to the Verein für Socialpolitik (German Economic Association): "A strong state, a state superior to the economy, where it belongs", in: Rüstow, "Interessenpolitik oder Staatspolitik?/Freie Wirtschaft - starker Staat", note 12 above, 62-69.

${ }^{19}$ C. Schmitt, "Starker Staat und gesunde Wirtschaft", in: G. Maschke (ed.), Carl Schmitt, Staat, Großraum, Nomos. Arbeiten aus den Jahren 1916-1969, (Duncker \& Humblot, [1933] 1995).

${ }^{20}$ Cf., above all, Böhm, note 15 above; Böhm, note 5 above (1936) and his again programmatic contribution to the first OrdoJahrbuch from 1948: "Das Reichsgericht und die Kartelle: eine wirtschaftsverfassungsrechtliche Kritik an dem Urteil des RG vom 4. Febr. 1897, RGZ 38/155", (1948) 1 Ordo: Jahrbuch für die Ordnung von Wirtschaft und Gesellschaft, 197-21.

${ }^{21}$ Foundational, see F. Böhm, Wirtschaftsverfassung und Staatsverfassung, (Mohr/Siebeck, 1950). On Böhm, above all, see R. Wiethölter, "Franz Böhm (1895-1977)", in: B. Diestelkamp and M. Stolleis (eds), Juristen an der Universität Frankfurt a.M., (Nomos Verlag, 1989), 207-252. 
Because of these boundaries to three sides - toward the totalitarian planned state, toward laissez-faire liberalism, towards the regulatory state - the idea of a "constitution for competition" guaranteed by the state was considered an attractive guiding principle for the reconstruction of the economic and legal order. Walter Hallstein is worthy of mention as one of the most influential advocates of this principle; in his 1946 lecture as president of the University of Frankfurt, ${ }^{22}$ he advocated the "restoration" of private law and of private-law freedoms, in line with the "Freiburg message". ${ }^{23}$

In the early Federal Republic, ordoliberalism was strong, but had unsecured flanks. One resulted from the tension between the (anti-interventionist) competition regime and the Basic Law's principle of the welfare state (which called for interventionist activism) - this line of conflict is personified in Alfred Müller-Armack, ${ }^{24}$ who praised the compatibility of his project of a "social market economy" with the "Freiburg message", although his praise was unable to dispel the ordoliberals' scepticism. More important was the second flank, namely, the weakness of the "constitution for competition". In his work on the history of German private law in the Weimar and Bonn Republics, Knut Wolfgang Nörr ${ }^{25}$ differentiates between two concepts that took effect in parallel and in opposition to each other in the course of (German) economic legal history: the "organised economy" and the "social market economy" (which he understands simply as an ordoliberal project). This coexistence of the "organised economy" on the one hand and ordoliberalism on the other, he claimed, had institutionalised a contradiction. In fact, ordoliberalism had dominated the thinking of only the scholars of private and economic law. In state, constitutional, and administrative law, the influence of the ordoliberal school remained weak, and, instead, the proponents of an organised and corporatist economic constitution were dominant. For this reason, Nörr diagnosed a two-pronged approach to economic policy and constitutional law as a basic phenomenon in the genesis of the Bonn Republic: "Concerning the economic order which was to shape the new state, we must speak of nothing less than a double mise-en-scène, of two productions of the same dramatic piece that were oblivious to each other." ${ }^{26}$ Dramatic encounters certainly did take place. They include two cases before the Federal Constitutional Court in which the ordoliberal postulate of an "economic constitution" structured along competitive lines was rejected. ${ }^{27}$

${ }^{22}$ W. Hallstein, "Wiederherstellung des Privatrechts", (1946) Süddeutsche Juristenzeitung, 1-7; differently, idem, "Von der Sozialisierung des Privatrechts", (1942) 102 Zeitschrift für die gesamten Staatswissenschaften, 530-546.

${ }^{23}$ On all this in more detail, see C. Joerges, "The Science of Private Law and the Nation-State", in: Francis Snyder (ed), The Europeanization of Law. The Legal Effects of European Integration, (Hart 2000, 47-82.; F. Kübler, "Wirtschaftsrecht in der Bundesrepublik - Versuch einer wissenschaftshistorischen Bestandsaufnahme", in: D. Simon (ed.), Rechtswissenschaft in der Bonner Republik. Studien zur Wissenschaftsgeschichte der Jurisprudenz, (Suhrkamp Verlag, 1994), 364-385.

${ }^{24}$ In the eyes of other orthodox ordoliberals such as Eucken or Röpke, the synthesis of the Catholic social doctrine and the Protestant ordoliberalism that Müller-Armack strove to achieve with his conception of a social irenics and the term "social market economy" made him a marginal figure in the ordoliberal paradigm, although he himself underlined his commitment to ordoliberalism (see C. Joerges and F. Rödl, “The 'Social Market Economy' as Europe's Social Model?", in: L. Magnusson and B. Stråth (eds), A European Social Citizenship? Preconditions for Future Policies in Historical Light, (Lang, 2005). His boss, Ludwig Erhard, is considered the politically most prominent ordoliberal; as an economist and professor in Nuremburg, he contributed little to the development of ordoliberal theory (but much too effectively marketing it to the public). Eucken and Böhm are undisputedly viewed as the founding fathers of ordoliberalism; Röpke and Rüstow are considered representatives of a sociological ordoliberalism; and Hayek, Hoppmann, and Mestmäcker represent the second generation, which combined elements from the Anglo-Saxon and the Austrian schools.

${ }^{25}$ K.W. Nörr, Die Republik der Wirtschaft. Teil I: Von der Besatzungszeit bis zur Großen Koalition, (Mohr/Siebeck, 1999), 5 ff.

${ }^{26}$ Ibid., 84.

${ }^{27}$ Investment aid judgment of 20 July 1954, BVerfGE 4, 7 and co-determination judgment of 1 March 1979, BVerfGE 50, 290. 


\section{Cultural Underpinnings and contexts of the political agenda of ordoliberalism since the Weimar Republic}

Just as is the case with its legal-theory aspects, the normative and ethical roots of ordoliberalism have hardly been mentioned in the debate about an "ordoliberalisation" of Europe.

The founding fathers of ordoliberalism saw the reasons for Weimar's decline not only in the undermining of the liberal competitive economy through cartels and monopolies.

For this reason, the churches were to be strengthened again as "powers providing order" (Eucken). Eucken had already commented in the 1930s that the loosening ties to the church had facilitated people turning to secularisms in the Weimar period and that "religion had increasingly lost the power to provide individuals' lives, and thus also their economic activity, a context of meaning". ${ }^{28}$ For this reason, the ordoliberals took an interesting, duplicitous approach: on the one hand, they invoked the churches as supporting authorities, while on the other, they sought to create a surrogate religion by incorporating strong underlying values. A "sociological liberalism" was to replace a "sociologically blind liberalism" and was to help "embed [the market] in a higher overall order". ${ }^{29}$ In reference to Weber, Woodruff calls this the attempt to develop a theodicy for the purpose of "adding an ethical dimension to the market". ${ }^{30}$ Böhm then emphasised that "competition" was the "morals of the free market economy" ${ }^{31}$ In so doing, the ordoliberals did not invent a genuinely new canon of values, but went back to what was tried and tested. Numerous "explicitly normative-anthropological deliberations" of the ordoliberals left their mark on "the strong affinity of a liberal ethos largely influenced by Protestantism". ${ }^{32}$

The "deep Protestant grammar" 33 of ordoliberalism was no accident. All the key figures of the first ordoliberal generation were Protestants. Eucken wrote in a 1942 letter to Rüstow: "I could neither live nor work if I did not believe that God exists." ${ }^{34}$ The ordoliberal project that developed in the late 1930s and early 1940s in the Freiburg circles was therefore the genuinely Protestant attempt to design an economic order. The project would later distance itself from the social-Catholic, the Keynesian-welfarestate, and the neoclassical Austrian-Anglo-Saxon competition. The key figure was the Protestant theologian Dietrich Bonhöffer. Between 1938 and 1944, he brought Protestant theologians (Otto Dibelius, Constantin von Dietze), Protestant economists (Walter Eucken, Leonard Miksch, Adolf Lampe), Protestant jurists (Franz Böhm, Hans Großmann-Doerth), and Protestant historians (Gerhard Ritter) together in the Bonhöffer Kreis and the Arbeitsgemeinschaft Erwin von Beckerath in Freiburg. ${ }^{35}$ The Freiburger Denkschrift, which originated from these circles and was to be the blueprint for postwar reconstruction, laid out the first coherent Protestant economic and social ethics.

\footnotetext{
${ }^{28}$ Eucken, note 13 above, 5-25.

${ }^{29}$ W. Röpke, Jenseits von Angebot und Nachfrage, 2nd ed.(Rentsch, 1958), 19.

${ }^{30}$ D.M. Woodruff, “Ordoliberalism, Polanyi, and the Theodicy of Markets”, J. Hien and C. Joerges (eds), Ordoliberalism, Law and the Rule of Economics, (Hart Publishing, 2017), 215-218.

${ }^{31}$ Böhm, note 15 above, 136.

${ }^{32}$ T. Jähnichen, "Die Protestantischen Wurzeln der Sozialen Marktwirtschaft", (2010) 1 Ethik und Gesellschaft, 49-58, at 11, 13.

${ }^{33}$ P. Manow, "Ordoliberalismus als ökonomische Ordnungstheologie", (2001) 29 Leviathan, 179-98; H. Rieter and M. Schmolz, "The Ideas of German Ordoliberalism 1938-45: Pointing the Way to a New Economic Order", (1993) 1 Journal of the History of Economic Thought, 87-114; H.-P. Reuter, "Vier Anmerkungen zu Philip Manow, "Die Soziale Marktwirtschaft als interkonfessioneller Kompromiss? Ein Re-Statement", (2010) 1 Ethik und Gesellschaft, 1-22; Jähnichen, note 32 above.

${ }^{34}$ H.O. Lenel, "Walter Eucken's Briefe an Alexander Rüstow", (1991) 42 ORDO: Jahrbuch für die Ordnung von Wirtschaft und Gesellschaft, 11-14, at 12.

${ }^{35}$ N. Goldschmidt, "Die Entstehung der Freiburger Kreise", (1997) Historisch-Politische Mitteilungen:Archiv für ChristlichDemokratische Politik, 1-17.
} 
Its underlying values clearly differentiate ordoliberalism from Anglo-Saxon liberalism. Although selfinterest, which drives people to compete with each other economically, does induce them to give their best, it can also bring them to manipulate competition to their own benefit. Just as in Protestantism, ordoliberalism considers people to be "neither angels nor devils", ${ }^{36}$ but rather "justified and sinners at the same time; that is why it is decisive to place them within an order that disciplines the peccator". ${ }^{37}$

The ordoliberal idea to employ the state as protector of the economic constitution reflects the Protestant continental-European views of human nature. Especially the US variants of ascetic Protestantism focus on the freedoms and rights of the individual. This often culminates in hostility toward the state which is alien to ordoliberals (sic!). Continental-European ascetic Protestantism attempted to strengthen the morally proper behaviour of its communities by creating a res publica christiana, a Christian state order. ${ }^{38}$ In his work, Eucken seeks a compromise between "a Calvinist theocracy with its near identity of church and state and the Lutheran two-kingdoms doctrine with its separation of the spiritual and secular spheres". ${ }^{39}$ His concepts mirror Bonhöffer's "authoritative-paternalistic [...] thinking" that "trusts an order and authority based on law and responsibility more than individual freedom". ${ }^{40}$

Ordoliberalism's notion of society is not paternalistic, even though the state's capability to provide order is so important to it. The state is supposed to hold back and limit itself to setting underlying conditions for the social order. Ordoliberals reject social transfer payments as false incentives. Unconditional transfers for reasons of solidarity would in the end result in the "total catastrophe for state and society" and make citizens "slaves of the state". ${ }^{41}$ Instead, the state should limit itself to ensuring equal opportunity and creating the conditions for helping people help themselves. The deep Protestant grammar of ordoliberalism gave it a specific concept of solidarity. Help should always be limited to what is absolutely necessary in order to set incentives for proper ethical behaviour (hard work, solidarity, frugality). ${ }^{42}$ This is the only way for people to liberate themselves from misery through their own efforts. That is the Protestant core of empowerment of the individual that results from the ordoliberal logic; this attitude is visible time and again in German politicians' discourse during the euro crisis.

Thus, ordoliberalism distinguished itself clearly from Catholic social ethics, the major religious and political doctrine opposing it in the 1950s and 1960s..$^{43}$ The Catholic conception of the human being assumes that individuals are not equipped with the same intellectual, moral, and physical capabilities. For this reason, ensuring fair and equal starting conditions and opportunities, as ordoliberals do, would not suffice for Catholic social ethics; instead, society must also guarantee a certain amount of redistribution. ${ }^{44}$ Nonetheless, both sides tried time and again to create a synthesis of the two Christian ideas about the economic system.

${ }^{36}$ C. von Dietze, Theologie und Nationalökonomie, (Tübingen/Stuttgart: Furche 1947), 26.

${ }^{37}$ Reuter, note 33 above, 3.

${ }^{38}$ P. Gorski, The Disciplinary Revolution: Calvinism and the Rise of the State in Early Modern Europe, (University of Chicago Press, 2003), 21; T. Petersen, "Die Sozialethik Emil Brunners und ihre Neoliberale Rezeption", HWWI Research Paper No. 5-6, 2008, 1-27, at 23; with Benedictine critical distance, E.E. Nawroth, Die Sozial- und Wirtschaftsphilosophie des Neoliberalismus, (Kerle, 1961).

39 Petersen, note 38 above, 23.

${ }^{40}$ H. Falcke, "Welche Ansätze Für Eine Wirtschaftsethik finden wir bei Dietrich Bonhoeffer?”, (2011) 71 Evangelische Theologie, 376-95, at 382.

${ }^{41}$ W. Röpke, Civitas humana : Grundfragen der Gesellschafts- und Wirtschaftsreform, 3rd ed., (Erlenbach-Zürich, 1949$), 257$.

${ }^{42}$ K. Dyson, "Ordoliberalism as Tradition and as Ideology", in: J. Hien and C. Joerges (eds), Ordoliberalism, Law and the Rule of Economics, (Hart Publishing, 2017).

${ }^{43}$ J. Hien, "Competing Ideas: The Religious Foundations of the German and Italian Welfare States. PhD Thesis. Fiesole: European University Institute, 2012, available at: http://cadmus.eui.eu/bitstream/handle/1814/24614/2012_Hien_AuthVersion.pdf?sequence=1\&isAllowed=y.

${ }^{44}$ Pius XI, Quadragesimo Anno, 1931, available at: http://w2.vatican.va/content/pius-xi/en/encyclicals/documents/hf_pxi_enc_19310515_quadragesimo-anno.html, 75, last accessed 22 August 2017; H. Pesch, Lehrbuch Der 
Müller-Armack's attempt to create a synthesis was the concept of the "social market economy". 45 Müller-Armack's "social irenics" did not meet with the approval of all representatives of ordoliberalism, but the term "social market economy" became so popular that ordoliberal purists began to claim the concept for themselves at the latest since Germany's economic miracle and Erhard's book "Prosperity through Competition". So a robust theoretical synthesis that did justice to the ideas of both the Protestant and the Catholic factions was never elaborated.

There were political tensions too. Although both the social-Catholic and the ordoliberal-Protestant factions had come together in the newly established Christian Democratic Union (CDU), the traditional mistrust with which social Catholicism approached economic liberalism soon regained the upper hand. The old alliances between Catholicism, economic corporatism, and the Bismarckian welfare state formed anew. ${ }^{46}$ The Protestant ordoliberals responded to this alliance with suspicion. The relationships being renewed were too similar to those they had opposed in the 1920s. The leading ordoliberals could not identify with and reconcile themselves to the de facto constitution of the Federal Republic's economy - its decidedly corporatist elements, the tendencies of political Catholicism toward economic democracy, and the restoration of the Bismarckian welfare state under the Catholic chancellor Adenauer. ${ }^{47}$ They saw Germany on the road to serfdom that Hayek had prophesied for welfare-state agendas. ${ }^{48}$

The negative attitude toward social policy also became important in the first federal cabinets, in the arguments between Adenauer, a Catholic, and Erhard, a Protestant. The controversy around the reform of the pension system between 1955 and 1957, which was to become the new foundation for the Federal Republic's welfare state, was the strongest. Erhard railed against the "poison of dynamization" and wanted to reduce pensions to a minimum. ${ }^{49}$ To Röpke, the planned reform was "the prosthesis of a society crippled by proletarism and crumbled to bits through massification". ${ }^{50}$

In the end, the ordoliberals had to concede defeat, and the presumably most popular reform of the postwar period was introduced. In return, Erhard was permitted to initiate the antitrust law, complete the Bundesbank Act, and construct the German Council of Economic Experts as an independent body in which ordoliberal expertise was to be bundled and be politically untouchable and which was to advise the Federal government. But in fact, the institutional agenda of the ordoliberals was constantly circumvented in the German "negotiation democracy". ${ }^{51}$ The German post-war order was therefore not only a compromise between capital and labour, as suggested by the term "social market economy", but

Nationalökonomie. 1. Grundlegung, (Freiburg im Breisgau: Herder, 1914), 83; F. Mazurek, "Die Konzeption Des Gesellschaftlichen Solidarismus Nach Heinrich Pesch“, (1980) 21 Jahrbuch Für Christliche Sozialwissenschaften, 73-98, at 83, 93; Nawroth, note 38 above.

${ }^{45}$ A. Müller-Armack, "Wirtschaftslenkung und Marktwirtschaft", in: idem (ed), Wirtschaftsordnung und Wirtschaftspolitik. Studien und Konzepte zur sozialen Marktwirtschaft und zur europäischen Integration, (Rombach, [1946] 1966), 19-170; idem, "Die Wirtschaftsordnungen sozial gesehen", in: idem, (ed), Wirtschaftsordnung und Wirtschaftspolitik. Studien und Konzepte zur sozialen Marktwirtschaft und zur europäischen Integration, (Rombach, [1948] 1966), 171-199.

${ }^{46}$ P. Manow, Social Protection, Capitalist Production. The Bismarckian Welfare State in the German Political Economy, 1880-2010, (Berlin-Bremen-Cologne, 2016), unpublished ms. (on file with authors), 84 ff.; Abelshauser, note 16 above, 93 ff.

${ }^{47}$ J. Hien, "The Ordoliberalism that Never Was", (2013) 12 Contemporary Political Theory, 349-358.

${ }^{48}$ F.A. v. Hayek, The Road to Serfdom, (Routledge, 1944).

49 V. Hentschel, Geschichte der Deutschen Sozialpolitik: 1880-1980, (Suhrkamp Verlag, 1983), 165.

${ }^{50}$ W. Röpke, "Gefahren des Wohlfahrtsstaats”, in: D. v. Schönwitz, K. Hohmann, H.-J Weber and H. Wünsche (eds), Grundtexte zur Sozialen Marktwirtschaft, (Gustav Fischer, 1958), 253-270, at 255.

51 The entire process is reconstructed in G. Brüggemeier, Entwicklung des Rechts im organisierten Kapitalismus, Band 2 , (Syndikat, 1979), $383 \mathrm{ff}$. 
a compromise between the social ethics and ideas about the economic system held by the two major religions in Germany, as Philip Manow emphasises. ${ }^{52}$

\section{The turn to Europe}

The relationship between ordoliberalism and the project of European integration was not one of mutual affection. ${ }^{53}$ The disappointments about Germany's economic and societal policies may have favoured the turn to Europe, but whether and to what extent such hopes were fulfilled is a different matter. On the side of the ordoliberal school, we see the willingness to cooperate, but also ex post facto rationalisations, adaptations, and finally failures. Three development phases can be differentiated.

\section{The formative phase of "constitutionalisation" of the EEC Treaty}

Ordoliberalism and its Ordnungstheorie were practically unknown beyond Germany's borders. Even within Germany, European law specialists, whose background was mainly in public law (Staatsrecht), hardly took note of ordoliberalism. ${ }^{54}$ Yet legal scholars and the courts certainly did set the tone in shaping the project of integration. But it was not ordoliberalism, but rather the project of "integration through law" which represented the legal field's claim to leadership, whereby law presented itself as a stringently constructed system - a doctrine in the style of German "jurisprudence of concepts." Summarised briefly:

Norms of the EEC Treaty which are sufficiently concrete apply directly in the Member States. Since these norms apply directly, they must take precedence over national law. This applies in particular to the fundamental economic freedoms which can be asserted by Europe's market citizens before the European Court of Justice, countering relevant national legislation. This Court safeguards the uniformity of European law. That is why its interpretation must be binding.

These are the core concepts whose interaction comprises the so-called constitutionalisation of the European Treaties. They have taken on paradigmatic significance, and have convinced and guided generations of lawyers. ${ }^{55}$ Political, social, and economic determinants of this development of the law were disregarded. The legal doctrine of European law cannot explain the success of this doctrine. Its practical impact only becomes intelligible based on how it functions for a project of integration conceived of as being market-rational. And it is within precisely this explanatory framework that it becomes understandable why the orthodoxy of European law is attractive to ordoliberalism: ${ }^{56}$ the freedoms guaranteed in the EEC Treaty, the opening up of national economies, the bans on discrimination, and the commitment to a system of undistorted competition were interpreted as a

\footnotetext{
52 P. Manow, "Modell Deutschland as an Interdenominational Compromise", CES Working Paper 003, 2000.

${ }^{53}$ Leading representatives of the ordoliberal school initially rejected the project of integration; cf., M. Wegmann, Früher Neoliberalismus und Europäische Integration, (Nomos Verlag, 2002), $313 \mathrm{ff}$.

${ }^{54}$ The doyen of the new discipline, Hans Peter Ipsen, was one of the exceptions, yet kept a critical distance from ordoliberalism in his seminal book Europäisches Gemeinschaftsrecht, (Mohr/Siebeck, 1972), 976 ff.).

55 D. Augenstein and M. Dawson, "What Law for what Polity? 'Integration through Law' in the European Union Revisited", in: D. Augenstein (ed.), "Integration through Law" Revisited: The Making of the European Polity, (Ashgate Publishing, 2013 ) with extensive references. One of the very rare critical voices is, prominently, D. Grimm, Europa ja - aber welches? Zur Verfassung der europäischen Demokratie, (C.H. Beck, 2016). - The impact has been documented not, as the author claims, in "the first historical analysis" but with particular care by R. Byberg, "The History of the Integration Through Law Project: Creating the Academic Expression of a Constitutional Legal Vision for Europe", (2017) 18 German Law Journal, 1532-1556; this euphemism in this work does justice do the enthusiasm and prudence of the founding fathers of the project but cannot camouflage the theoretical poverty of its conceptual frame.

${ }^{56}$ Cf., already, C. Joerges, "The Market without a State? States without Markets? Two Essays on the Law of the European Economy", EUI Working Paper Law 1/96, San Domenico di Fiesole 1996 (http://eiop.or.at/eiop/texte/1997-019 and 020.htm); idem, "Economic Law, the Nation-State and the Maastricht Treaty", in: R. Dehousse (ed.), Europe after Maastricht: an Ever Closer Union? (C.H. Beck, 1994), 29-62.
} 
"decision" in favour of an economic constitution conforming to the underlying conditions of a marketbased order. The EEC could be understood as a legal order committed to maintaining economic freedoms and protecting competition by means of supranational institutions that precisely because of this gained a constitutional legitimacy independent of that of the democratic nation-state - and that simultaneously placed limits on the Community's scope of political action. ${ }^{57}$ In this way, ordoliberalism was able to answer the question about the legitimacy of the project of integration more conclusively than the prevailing orthodoxy. The fact that the EEC had constituted itself as a "market without a state" 58 did not raise eyebrows. Independent institutions that cannot be guided politically certainly do satisfy an ordoliberal constitution of the economy, once the "basic decision" in favour of such an order has been taken.

So, even during the formative phase of the process of integration, do we already have to contend with it "ordoliberalising" Europe? Such an assumption would amount to the mere possibility of a reconstruction of the project of integration along ordoliberal lines being taken at face value. The ordoliberal vision of an autonomous transnational economic constitution was a normative project that was hardly noticed, let alone recognized, outside of Europe. As Abelshauser showed ${ }^{59}$ it was impossible to reach consensus about it even between the Ministry for Economic Affairs and the Federal Foreign Office. Giandomenico Majone observes soberly and soberingly: ${ }^{60}$ in the 1950 s, planification and interventionist practices were commonplace in the founding states in all sectors of the economy - how could defeated Germany, of all countries, have been able to prevail in Europe with a liberal Ordnungspolitik that could not even be implemented domestically? Is it legitimate to present the acceptance found by the chapter on competition policy as an ordoliberal moment even though it appears simply imperative that the continued existence of barriers to trade is incompatible with the agenda of market integration; that, on the one hand, governments must be kept from creating a competitive advantage for their own economies through subsidies, and, on the other, companies must not be permitted to organise market compartmentalisation? After all this, even limiting the Community to the economy and by doing so foregoing a European labour and social constitution, which indeed initiated the "decoupling" of the social dimension from the institutionalisation of Europeanised "undistorted competition", ${ }^{61}$ cannot be exposed so easily as (backhanded) cunning on the part of ordoliberal reason. Did it not stand to reason instead to set aside such efforts to expand and deepen the project of integration because opening up the national economies and removing barriers to trade were considered a win-win matter even by socially oriented economists ${ }^{62}$ and it could be assumed that the social security systems organised along nation-state lines would remain

\footnotetext{
${ }^{57}$ Instructive, A. Müller-Armack, "Die Wirtschaftsordnung des Gemeinsamen Marktes”, in: idem (ed.), Wirtschaftsordnung und Wirtschaftspolitik. Studien und Konzepte zur sozialen Marktwirtschaft und zur europäischen Integration, (Rombach: 1966), 401-415, at $401 \mathrm{ff}$.

${ }^{58}$ C. Joerges, "Markt ohne Staat? Die Wirtschaftsverfassung der Gemeinschaft und die regulative Politik", in: R. Wildenmann (ed), Staatswerdung Europas? Optionen einer Europäischen Union, (Baden-Baden.1991), 225-268.

${ }^{59}$ W. Abelshauser, "Deutsche Wirtschaftspolitik zwischen europäischer Integration und Weltmarktorientierung”, in: idem (ed), Das Bundeswirtschaftsministerium in der Ära der Sozialen Marktwirtschaft. Der deutsche Weg der Wirtschaftspolitik, (Walter de Gruyter, 2016), 482-581, at $537 \mathrm{ff}$.

${ }^{60}$ G. Majone, Rethinking the Union of Europe Post-Crisis. Has Integration Gone Too Far?,(Cambridge University Press, 2010), 90 ff; in depth, A. Milward, The European Rescue of the Nation State, (Routledge, 1992).

${ }^{61}$ F.W. Scharpf, "The European Social Model: Coping with the Challenges of Diversity", (2002) 40 Journal of Common Market Studies, 645-670, at 645 f.

${ }^{62}$ Cf. especially the "Ohlin Report” of the International Labour Organization 1956, 99-123.
} 
intact in the golden age of "embedded liberalism"? ${ }^{6364}$ It is telling that ordoliberal protagonists were undeterred by such declarations in their own interpretation of integration. ${ }^{65}$

\section{Von Hayek's and Mestmäcker's “Neo-ordoliberalism”}

Europe's integration through law experienced and withstood many a crisis, therefore progressing only slowly - until in 1985 Delors, the charismatic President of the Commission, triggered an unprecedented dynamic with his "White Paper on completion of the internal market" ${ }^{66}$ Its agenda was met with strong approval by the ordoliberal camp, but just as in the previous section on the "constitutionalisation of the treaties" and the "integration through law," it would be too simplistic to conclude again that an "ordoliberalisation" of Europe were taking place on the basis of the affinities between the practice of integration policy and its theoretical reconstruction.

The affinities and discrepancies between Delors's internal market initiative and the ambitions of the ordoliberal school become apparent when placed in the context of the revision of ordoliberal legal theory, which was carried out in the national context as early as the 1960s. ${ }^{67}$ It was a revision of paradigmatic dimensions. It took place when Friedrich A. von Hayek returned from Chicago to succeed ur-Freiburger Walter Eucken. Von Hayek's theorem of "competition as a discovery procedure" 68 became the new guiding star for the second generation of German post-war ordoliberalism. Erich Hoppmann, who was appointed von Hayek's successor in Freiburg in 1968 and then became director of the Walter Eucken Institut in 1970, again as von Hayek's successor, was decisive in keeping the connection between economics and jurisprudence alive. His congenial companion as a legal scholar was Ernst-Joachim Mestmäcker, a student of Böhm's, who was the leading theorist and also the most influential representative of the new generation. The opinions on the internal market initiative by the protagonists of the ordoliberal tradition, specifically those of the Board of Academic Advisors to the Federal Ministry for Economic Affairs ${ }^{69}$ and the Monopolies Commission, ${ }^{70}$ are to be seen against this background.

The principle of "mutual recognition" of product standards and regulations, which was introduced by the ECJ's legendary Cassis ruling and systematically developed in the Commission's White Paper, was understood as institutionalising a regulatory competition which was to expose national laws to an international competition for the "best" regulation. Tendencies in the ECJ's rulings to have European antitrust law strengthen the supervision of national legislation were understood in the same vein. This reorientation of antitrust law centred on a core element of the ordoliberal tradition, namely controlling

${ }^{63}$ On the concept, see J.G. Ruggie, "International Regimes, Transactions and Change: Embedded Liberalism in the Postwar Economic Order", (1982) 36 International Organization, 375-415; J. Steffek, Embedded Liberalism and its Critics: Justifying Global Governance in the American Century, (Springer, 2006).

${ }^{64}$ Cf. S. Giubboni, Social Rights and Market Freedoms in the European Constitution. A Labour Law Perspective, (Cambridge University Press, 2006), who argues: "[T]he apparent flimsiness of the social provisions of the Treaty of Rome (and of the slightly less meagre ones of the Treaty of Paris) was in reality consistent with the intention, imbued with the embedded liberalism compromise, not only to preserve but hopefully to expand and strengthen the Member States' powers of economic intervention and social governance: i.e., their ability to keep the promise of protection underlying the new social contract signed by their own citizens at the end of the war" (loc. cit., 16); similarly F. Rödl, "Arbeitsverfassung”, in: A. v. Bogdandy and J. Bast (eds), Europäisches Verfassungsrecht, 2nd ed. (Springer, 2009), 855-904, at 867.

${ }^{65}$ Cf. the references in W. Sauter and H. Schepel, State and Market in European Union Law: The Public and Private Spheres of the Internal Market before the EU Courts, (Cambridge University Press, 2009), 13-15.

${ }^{66}$ Commission of the EC 1985.

${ }^{67}$ Pierre Dardot and Christian Laval call this turnaround "neo-ordoliberalism" (Dardot \& Laval, note 2 above, $205 \mathrm{ff}$ ).

${ }^{68}$ F.A. v. Hayek, "Wettbewerb als Entdeckungsverfahren", reprinted in idem, Freiburger Studien. Gesammelte Aufsätze, (Mohr, 1969), 249-265.

${ }^{69}$ Board of Academic Advisors to the Federal Ministry for Economic Affairs 1986.

70 Monopolies Commission 1990, 401. 
private power by controlling competition. The Chicago School declared this objective misguided because it did not promote efficiency at all. In effect, this corresponded to the notions of Hayek's theory of "competition as a discovery procedure", which the legal scholars of the "second generation" of the ordoliberal school had adopted. ${ }^{71}$ Protecting the freedom of entrepreneurial activities, they maintained, required above all striking down anticompetitive regulations and limiting government subsidies. Deregulation and privatisation policies now determined Europe's agenda. As was already the case in the formative phase of the project of integration, it would again be premature to conclude, on the basis of these affinities between the reorientations of the "second generation" and Anglo-Saxon neoliberalism, which had been adopted in Europe, that German "neo-ordoliberalism" was successful. ${ }^{72}$

Besides these affinities, however, there were also considerable discrepancies. They became manifest when the internal market initiative entangled the Community in a growing number of social regulatory issues concerning environmental, labour, and consumer protection and established an increasingly extensive regulatory machinery. It was now about re-regulation, not de-regulation, a finding that had to irritate Anglo-Saxon neoliberals and German neo-ordoliberals. ${ }^{73}$ The weight and the dynamics of the new regulatory policies were ignored or underestimated by Ordnungstheorie and Ordnungspolitik. ${ }^{74}$ The new chapter on industrial policy was taken note of - and rejected ${ }^{75}$ Once the European policy competencies had been broadened and the relevant regulatory bodies had been established, it was no longer comprehensible how one could continue to assign a constitutional core function to the "system of undistorted competition". It had become clear that Europe placed little trust in "competition as a discovery procedure". ${ }^{76}$ Ordoliberalism adopted a critical distance. ${ }^{77}$

\section{The Economic and Monetary Union (EMU) in the Maastricht Treaty as a pyrrhic victory}

The Maastricht Treaty was the hitherto most ambitious integration project. The competencies of the project, which was from then on called "Union", were expanded to include environmental and industrial policy. A European polity emerged. The approaches of a "social Europe" were strengthened. An "ever

${ }^{71}$ C. Joerges, "What is Left of the European Economic Constitution? A Melancholic Eulogy", (2005) 30 European Law Review, 461-489, at $472 \mathrm{ff}$.

72 D. Bartalevich, "Do Economic Theories Inform Policy? Analysis of the Influence of the Chicago School on European Union Competition Policy", Ph.D thesis, Copenhagen Business School, 2017, available at: http://openarchive.cbs.dk/handle/10398/9530, last accessed 22 August 2017; A. Wigger, "Debunking the Myth of the Ordoliberal Influence on Post-war European Integration”, in: J. Hien and C. Joerges (eds), Ordoliberalism, Law and the Rule of Economics, (Hart Publishing, 2017), 161-178.

${ }^{73}$ First recognised very clearly and elaborated programmatically by Giandomenico Majone (G. Majone, "Regulating Europe: Problems and Prospects", (1989) 3 Jahrbuch zur Staats- und Verwaltungswissenschaft, 159-177; idem, Deregulation or Re-Regulation? Regulatory Reform in Europe and the United States, (St. Martin's, 1990).

${ }^{74}$ The fact that Ordnungstheorie did not address the problems of the "risk society" corresponds to its fixation on competition. In risk society, decision problems arise that cannot be handled by market participants' decisions; cf. M. Everson and C. Joerges, "Consumer Citizenship in Postnational Constellations?", in: K. Soper and F. Trentmann (eds), Citizenship and Consumption, (Palgrave Macmillan, 2008), 154-171.

75 See W. Mussler, Die Wirtschaftsverfassung der Europäischen Gemeinschaft im Wandel. Von Rom nach Maastricht, (Nomos Verlag, 1998), 166 ff; M.E. Streit and W. Mussler, "The Economic Constitution of the European Community. From 'Rome' to "Maastricht", 19951 European Law Journal, 5-30; P. Behrens, "Die Wirtschaftsverfassung der Europäischen Gemeinschaft”, in: G. Brüggemeier (ed.), Verfassungen für ein ziviles Europa, (Nomos Verlag, 1994; E.J. Mestmäcker, "On the Legitimacy of European Law", in: idem (ed.), Wirtschaft und Verfassung in der Europäischen Union. Beiträge zu Recht, Theorie und Politik der europäischen Integration, (Nomos Verlag, [1993] 2003), $133 \mathrm{ff}$.

${ }^{76}$ W. Sauter, Competition Law and Industrial Policy in the EU, (Oxford University Press, 1997), $26 \mathrm{ff.}$

77 See Streit and Mussler, note 75 above, and Behrens, note 75 above, 73-90. The fact that the plurality of constitutional requirements relativizes the relevance of the system of undistorted competition was certainly registered by E.-J. Mestmäcker and H. Schweitzer, Europäisches Wettbewerbsrecht, 2nd ed., (C.H. Beck, 2004), 112 ff., but they add that "in the German-language literature [...] the primacy of an overall order characterized by the internal market and undistorted competition had prevailed". 
closer Union" was to develop. There was nothing genuinely ordoliberal about any of this. But there was also the Economic and Monetary Union: an independent central bank, the commitment to price stability, support for the currency through a Stability Pact. Was all this not ordoliberal?

Concerning the argument accompanying the treaty coming into existence, we must refer to the relevant analyses. ${ }^{78}$ Here, we limit our observations to a legal dispute: the Maastricht Treaty was brought before the German Federal Constitutional Court, whose decision of 12 October 1993 caused quite a sensation and shock among scholars of European law: ${ }^{79}$ the Community, the court claimed, was merely an association of states; the Federal Constitutional Court had the right to review whether the system of power was being heeded; allegiance to "ultra vires legal acts" was to be refused. The Constitutional Court also found that it was a dictate of democracy for the populace to have the opportunity "to give legal expression [...] to that which - relatively homogeneously - joins it together intellectually, socially, and politically". 80

The criticism triggered by all this ${ }^{81}$ drew attention away from arguments put forward by the complainants that are much more important in our context: in particular, they claimed that the European Union had such far-reaching competencies that the nation-states were no longer in a position to discharge important tasks. This erosion of national statehood, they asserted, called the continued existence of democratic statehood into question altogether. This line of argument prompted the Federal Constitutional Court to position the constitutional democracy of the Federal Republic of Germany in opposition to the continuing erosion of its statehood. Although the ruling ultimately approved European integration, it arrived at this result by taking up ordoliberal theorems. In the process, it itself subverted its demand for preserving democratic decision-making power and relinquished the Member States' political control over their economies.

How was that possible, and why did nobody notice? One fundamental contradiction in the reasons given for the ruling actually appears obvious. It is true that the Federal Constitutional Court declares that "fundamental" powers are to be left to the Bundestag as an essential constitutional requirement. But then the reasons given for the ruling make a strictly ordoliberal about-face: economic integration, the court said, was a non-political process that was taking shape autonomously and beyond the Member States. The Monetary Union needed functional legitimacy which was to be appropriately institutionalised by means of a constitutional duty to guarantee price stability and regulations to counter excessive budget deficits. By putting such institutional provisos into practice, the court concluded, the objections against the democratic legitimacy of economic integration had resolved themselves. In other words, the European Union is permitted to constitutionalise itself as a "market without a state", and its Member States may transform themselves into "states without markets". 82

\footnotetext{
${ }^{78}$ Especially K. Dyson, The Road to Maastricht: Negotiating Economic and Monetary Union, (Oxford University Press, 1999).

79 BVerfG 89, 155.

${ }^{80}$ Loc. cit., 186.

81 J.H.H. Weiler, "Does Europe Need a Constitution? Reflections on Demos, Telos and the German Maastricht Decision", (1995) 1 European Law Journal, 219-258, at 219 ff. B.-O. Bryde, "Die bundesrepublikanische Volksdemokratie als Irrweg der Demokratietheorie", (1994) 5 Staatswissenschaften und Staatspraxis, 305-330. This assertion that none exists may be incorrect, for nobody can gain an overview of the immense literature on the Maastricht judgment; however, it is true that even an analysis as comprehensive as that by Franz C. Mayer (F.C. Mayer, Kompetenzüberschreitung und Letztentscheidung. Das Maastricht-Urteil des Bundesverfassungsgerichts und die Letztentscheidung über Ultra-vires-Akte in Mehrebenensystemen; eine rechtsvergleichende Betrachtung von Konflikten zwischen Gerichten am Beispiel der EU und der USA, (C.H. Beck, 2000) does not deal with the decision's problématique relating to the law of the economic constitution.

${ }^{82}$ Cf. already, C. Joerges, "States without a Market? Comments on the German Constitutional Court's Maastricht-Judgment and a Plea for Interdisciplinary Discourses”, 1996, available at: http://eiop.or.at/eiop/texte/1997-020.htm, last accessed 22 August 2017.
} 
This entailed a fair bit of hubris. The Monetary Union certainly depended on Germany. But was this to mean that it could be subjected to German conditions? The German Federal Constitutional Court emphasised this point with a threat: "The concept of the Monetary Union as a 'Stabilitätsgemeinschaft' (community of stability) is the basis and the object of the German law approving [entry into the union]. If the Monetary Union should be unable to continue to develop the stability existing at the beginning of the third phase in accordance with the agreed commitment to ensure stability, then it would abandon the contractual conception." And if it should turn out "that the desired Monetary Union cannot be realized without an (as yet undesired) political union", then a new political decision about how to proceed further would be required.$^{83}$ Paul Kirchhof, the reporting Justice of the 2nd Senate, was an expert in public law and a Catholic, and not a "recognised" ordoliberal in either identity. It is all the more remarkable that he attempted to clarify the indeterminacies of the treaty text by means of a concept that reads as if it were ordoliberal and that was to make this interpretation binding across Europe. However, it very rapidly turned out that this was wishful thinking when that which was never to happen, according to the decision, actually did happen: the "community of stability" proved unstable. When in 1998, before entry into the third stage of the Monetary Union, the German Federal Constitutional Court was confronted with the demand to review whether the criteria it had formulated itself were being respected, the court had no other option but to refer to the prerogatives of the responsible state bodies to assess the matter. ${ }^{84}$ This was where the law entered into the crisis mode of European governance: political constraints prevailed over the legally formulated provisions ${ }^{85}$ Hardly less astonishing than the statements by the Federal Constitutional Court on the legally binding nature of the "community of stability" was Mestmäcker's assessment of the situation in 2007: "Trust in independent institutions, represented by German experiences with the Federal Constitutional Court and the Bundesbank, was probably the most important German contribution to the constitutional structure of the EC." ${ }^{\prime 6}$ To be sure, this statement predates the crisis. But even in 2007, this was the same type of wishful thinking that we observed in the earlier phases of the project of integration. ${ }^{87}$

\section{Crisis policy: An "Ordoliberalisation of Europe" or the failure of the ordoliberal project?}

What is the state of the frequently invoked "ordoliberalisation of Europe"? ${ }^{88}$ Did ordoliberalisation prevail thanks to the crisis, whereas in the decades before it had made little impact and had remained wishful thinking? How could we tell? (1) By the Maastricht Treaty and the economic and monetary policy agreed in it? (2) By the crisis policy measures? (3) By the rulings on crisis policy? - Time and again in our discussion of these broad questions, we encounter the patterns that we faced throughout our reconstruction of the reception history of ordoliberalism.

(1) The agreement on the Economic and Monetary Union (EMU) is largely considered the high point of the project of the internal market. The same is true of the assumption that the Monetary Union was a construct permeated with ordoliberalism. This is indeed corroborated by important factual, substantial, and institutional evidence. The most important evidence in factual terms is the commitment of monetary policy to price stability (Art. 127 TFEU; ex Article 105 EC Treaty), compliance with which the Federal

\footnotetext{
${ }^{83}$ BVerfG 89, 155, margin numbers 90, 93.

${ }^{84}$ Decision of 31 March 1998, BVerfGE [Decisions of the Federal Constitutional Court] 97, 350.

${ }^{85}$ This was repeated in the most dramatic terms in the argument between the Federal Constitutional Court and the ECJ about the ECB's OMT programme, which we discuss in Section 6. (3); "pereat iustitia, fiat mundus" (C. Joerges, (2016) 23 Maastricht Journal of European \& Comparative Law, 99-118) is a description that seeks to point out the renunciation of the law, but is not intended to insinuate, for example, that the EMU or its interpretation by the Federal Constitutional Court were "just".

${ }^{86}$ E.-J. Mestmäcker, "Europäische Prüfsteine der Herrschaft und des Rechts", (2007) 57 ORDO: Jahrbuch für die Ordnung von Wirtschaft und Gesellschaft, 3-16, at 12.

${ }^{87}$ Cf. Section 5, a), b), c).

${ }^{88}$ Blyth, note 2 above, 142.
} 
Constitutional Court declared to be a precondition for Germany's joining the Monetary Union, only to declare the stability of the "community of stability" to be a sine qua non of its binding nature for Germany. ${ }^{89}$ The most important institutional indicator is the establishment of the ECB and its being endowed with a degree of independence that is significantly greater than that of the German Bundesbank. Nonetheless, giving up the D-Mark remained very highly controversial among German economists. "The excessively hasty introduction of a European Monetary Union will expose Western Europe to strong economic tensions that could bring about a crucial political test in the foreseeable future, thereby endangering the goal of integration", read one of the 11 points of a critical memorandum..$^{90}$ Ultimately, what was likely decisive was not the discourse among experts, but politics. ${ }^{91}$

We are not trying to reconstruct the processes of how it came into existence in order to determine which reasons were ultimately decisive; clearly, we are instead focusing on the body of rules established by the Maastricht Treaty. This regime lacks essential characteristics of a constitutional order. Instead, the EMU institutionalised a constellation of conflict that cannot be resolved. This came about by assigning monetary policy to the Union level, but retaining the nation-states' responsibility for fiscal and economic policy, thus installing actors with markedly different preferences and interests for interdependent policy fields without creating a framework which would have allowed the political and economic conflicts arising from this situation to be resolved. The Stability Pact, which complements the EMU, was a lex imperfecta, and the Union's competency to coordinate (Art. 121 TFEU) was feeble. However, the policy's incoherences and laxness were by no means an accident or the result of poor craftsmanship in designing the treaty. National parliaments' power of the purse is the core competency of parliaments in democracies. Nobody could expect of the Member States that they would relinquish fiscal policy in addition to monetary policy. Yet the protagonists of the EMU were certainly aware of the differences between economic cultures, including those within the euro area. They would also have had to acknowledge that the Union did not meet the conditions of an optimal currency area. A stipulation that strict rules would apply was therefore simply out of the question. It could only be about having as much leeway as possible for fine-tuning and political compromises - borne by that culture of unlimited optimism that European politics has relied on time and again. ${ }^{92}$

(2) Was the crisis of the ordoliberal or neoliberal agenda at least followed by pertinent reactions, as was reported everywhere ?3 $^{93}$ The flood of norms alone that are to bring the financial, sovereign debt, and economic crises under control should give pause. The collection of relevant legal texts compiled by Fernando Losada and Agustín José Menéndez, ${ }^{94}$ which does not even document the regulations subsequently introduced in the Member States, runs to 800 pages. ${ }^{95}$ The extent and the density of this body of rules show that the crisis policy seeks to leave nothing to Hayek's "competition as a discovery procedure" ${ }^{96}$ and blithely disregards the cautioning words from his Nobel Prize acceptance speech about

\footnotetext{
${ }^{89}$ BVerfG 89, 155.

${ }^{90}$ Memorandum führender deutscher Wirtschaftswissenschaftler zur Währungsunion vom 11. Juni 1992, available at: http://www.dasgelbeforum.net/forum_entry.php?id=211943\&page=22\&category=0\&order=time.

91 Abelshauser, note 59 above, $555 \mathrm{ff}$.

92 Majone, note 60 above, $58 \mathrm{ff}$.

${ }^{93}$ Most recently, again with philosophical aspirations, Oksala, note 2 above, 181-196.

${ }^{94}$ F. Losada and A.J. Menéndez, "The Key Legal Texts of the European Crises. Treaties, Regulations, Directives, Case Law”, Oslo: ARENA Centre for European Studies, 2014; available at: http://www.sv.uio.no/arena/english/research/ publications/publications-2014/menendez-losada-legal-texts-v01-120614.pdf., last accessed 22 August 2017.

95 This is documented meticulously by a project of the European University Institute: Constitutional Change through Euro Crisis Law. A Multi-level Legal Analysis of Economic and Monetary Union. http://eurocrisislaw.eui.eu, last accessed 22 July 2017.

${ }^{96}$ v. Hayek, note 68 above.
} 
presumption of knowledge ${ }^{97}$. Instead, the agenda of the crisis policy is to force structural convergence in the euro area. ${ }^{98}$ Not only von Hayek, but also Walter Eucken would be horrified: von Hayek because the massive interventionism disregards his economic-policy warnings and normative positions; Eucken because although the procedures of the crisis policy are supposed to increase "competitiveness" everywhere, the stony path to this faraway goal is pursued with economic-policy tools that have nothing in common with Eucken's Ordnungspolitik.

But do the TSCG, the debt brake, the increasing competitiveness not correspond to the ordoliberal canon of values? Will, for this reason, an economic system be institutionalized in the end that respects and insists on market processes? For the time being, it is unforeseeable how and when the new forms of economic governance could be transformed into an Ordnungspolitik in the sense of the ordoliberal tradition. The specific feature of this policy was its legal force, the interdependency of legal order and economic order: Foucault understood this interdependency as follows: "What does applying the principle of the rule of law in the economic order mean? Roughly, I think it means that the state can make legal interventions in the economic order only if these legal interventions take the form solely of the introduction of formal principles. There can only be formal economic legislation. This is the principle of the Rule of law in the economic order." policy bound to justiciable criteria that Ernst-Joachim Mestmäcker declared to be indispensable. ${ }^{101}$

(3) The likely most important ECJ decision since the famous reasons for the direct effect of sufficiently concrete provisions of the EEC Treaty in $1963^{102}$ is the Gauweiler decision of 16 June $2015 .{ }^{103}$ The ECJ had to examine the question presented to it by the German Federal Constitutional Court whether the ECB was respecting the limits on its monetary-policy mandate or was rather arrogating the economicpolicy competencies reserved for the Member States when it bought bonds from Member States that had gotten into financial difficulties, insisting that "[t]he granting of any financial assistance" remain bound to the "strict conditionality" that was demanded in return for the financial assistance (Art. 136 III TFEU). These conditionalities concern the financial- and economic-policy conduct of the Member State in question. Here, the ECJ considered itself authorized to clarify the constellation of conflict that was institutionalised with the establishment of the EMU: the Bank had been assigned a technically highly complex task, namely monetary policy, the fulfilment of which required relevant expertise. Performing this task independently, the court said, included the freedom of the ECB to determine autonomously what was required in terms of monetary policy. The assessment by the ECB of the economic situation and the ECB's measures were legal, provided that "no obvious mistake in assessment could be determined". ${ }^{104}$ The Gauweiler decision legalized the transformation of the economic order into a technocratic regime that owes nobody political responsibility and that draws its legitimacy from its expertise. Of course, this is a type of expertise that cannot rely on proven knowledge, but demands that its discretionary decisions in dealing with situations of uncertainty are respected as a matter of

\footnotetext{
${ }^{97}$ F.A. v. Hayek, Die Anmaßung von Wissen: Die Irrtümer des Sozialismus, (Siebeck, 1996).

${ }^{98}$ F.W. Scharpf, "Forced Structural Convergence in the Eurozone”, MPIfG Discussion Paper 16/15, 2016

${ }^{99}$ M. Hadeed, "The Ordoliberal Ghost”, (2017), available at: https://www.socialeurope.eu/the-ordoliberal-ghost, last accessed 22 August 2017; incidentally, Eucken 1952, 245 ff. emphasises the context dependence of the form of competitive-based orders.

${ }^{100}$ Foucault, note 6 above, 171.

${ }^{101}$ E.-J. Mestmäcker, 'Power, Law and Economic Constitution', German Economic Review, (1973) 2, 177-198.; instructive also the criticism of Posner's economic legal theory in E.-J. Mestmäcker, A Legal Theory without Law. Posner v. Hayek on Economic Analysis of Law, (Mohr/Siebeck, 2007).

102 Case 26-62, van Gend \& Loos v Netherlands Inland Revenue Administration, Judgment of the Court of 5 February 1963. EUR-Lex - 61962CJ0026_SUM - EN

103 ECJ, Case C-62/14, Judgment of the Court (Grand Chamber), 16 June 2015, Peter Gauweiler and others v Deutscher Bundestag, ECLI:EU:C:2015:400.

${ }^{104}$ Ibid., para. 74.
} 
principle. ${ }^{105}$ This case was observed and applauded in all the subdisciplines of European Studies, that is, by scholars of the law, politics, and economics. ${ }^{106}$ Following this development, it is no longer clear how ordoliberalism, a theory of economic law, could defend its theoretical core characteristics, namely commitment to the rule of law and guidance of economic policy by justiciable criteria.

\section{The disintegration of ordoliberalism in economic science}

So far, we have documented only the progressing "delegalisation" of "economic governance" that has culminated in the crisis policy. But the economic foundations of ordoliberalism have lost some of their previous attractiveness as well. This is a process extending far back into the last century. ${ }^{107}$ After the turn of the millennium, nothing less than a jolt of formalisation and modelling permeated the field of economic science in Germany. Ordnungsökonomik, which was sceptical about the mathematisation of the discipline and had a strong philosophical and normative orientation, slipped into the margins. ${ }^{108}$ Apparently, it could no longer survive internationally in light of the dominance of universalistic AngloSaxon microeconomics. Young German economists were faced with the choice of either turning away from the classical Ordnungsökonomik or being unable to keep up internationally. The Cologne methods dispute, which was sparked when six professorships previously tailored to Ordnungspolitik were to be filled, attracted considerable attention. Following two appeals published in the Frankfurter Allgemeine Zeitung and the Handelsblatt, a harsh exchange ensued in which 83 ordoliberals and 188 modernisers spoke out. ${ }^{109}$ The strongest critics of the reorientation included Hans Willgerodt (a nephew of Wilhelm Röpke, member of the Kronberger Kreis, and publisher of the Ordo Jahrbuch) and Christian Watrin (a student of Müller-Armack), both professors emeritus at Cologne University and representatives of Ordnungsökonomik. Both had directed the Institute for Economic Policy at the University of Cologne, which had been founded by Müller-Armack. The ordoliberal economists criticized modern economics for the wide discrepancy "between formal models defined for artificial worlds - [...] and the economic policy problems arising in our experiential world with its real institutions and real people". ${ }^{110}$ German economists working abroad stated: "German economics is fossilized"; 111 "many of the purely verbal

105 On this difference: J. White, "Policy Between Rule and Discretion", in: J. Hien and C. Joerges (eds), Ordoliberalism, Law and the Rule of Economics, (Hart Publishing, 2017), 289-300.

${ }^{106}$ For the second time, the Federal Constitutional Court referred the matter to another court on 18 July 2017. The court's ruling here questions the ECB's policy of "quantitative easing", stating that it might be a form of public sector finance that is incompatible with the Gauweiler decision: BVerfG, Decision of the Second Senate of 18 July 2017- 2 BvR 859/15 paras. (1-137). The ECJ's response can be expected to take some months. Its conclusion is foreseeable; cf. M. Goldmann, "Summer of Love: Karlsruhe Refers the QE Case to Luxembourg", 2017, available at: http://verfassungsblog.de/summerof-love-karlsruhe-refers-the-qe-case-to-luxembourg, last accessed 22 August 2017.

107 A. Nützenadel, Der Ökonomen. Wissenschaft, Politik und Expertenkultur in der Bundesrepublik 1949-1974, (Vandenhoeck \& Ruprecht, 2005), esp. $33 \mathrm{ff}$.

108 R. Sala, "Methodologische Positionen und soziale Praktiken in der Volkswirtschaftslehre: Der Ökonom Walter Eucken in der Weimarer Republik", 2011, WZB Discussion Paper, No. SP IV 2011-401; U. Dathe, "Walter Euckens Weg zum Liberalismus (1918-1934)", (2009) 65 ORDO: Jahrbuch für die Ordnung von Wirtschaft und Gesellschaft, 53-86; J. Zweynert, "Die Entstehung Ordnungsökonomischer Paradigmen: Theoriegeschichtliche Betrachtungen”, 2007, Freiburger Diskussionspapiere zur Ordnungsökonomik 07/8.

109 V. Caspari and B. Schefold, Wohin steuert die ökonomische Wissenschaft? Ein Methodenstreit in der Volkswirtschaftslehre, (Campus Verlag, 2011).

${ }^{110}$ V. Vanberg, "Die Ökonomie ist keine zweite Physik", Frankfurter Allgemeine Zeitung 13 April 2009, available at: http://www.faz.net/aktuell/wirtschaft/wirtschaftswissen/wissenschaft-die-oekonomik-ist-keine-zweite-physik1792335.html, last accessed 22 August 2017.

111 C. Dustmann, "Deutsche VWL ist verknöchert", Handelsblatt, 4 May 2009, available at: http://www.handelsblatt.com/politik/konjunktur/oekonomie/nachrichten/oekonomenstreit-christian-dustmann-deutschevwl-ist-verknoechert/3169706.html, last accessed 22 August 2017. 
analyses to be found, for instance, in German-language journals [are] deeply permeated by ideology." 112 They criticised the "separate path taken in Germany" which, they alleged, meant withdrawing into its "national shell". ${ }^{113}$ German economists working in the US faulted a "doctrinaire provincialism" of "philosopher-economic policymakers in the German tradition" and called the Cologne methods dispute a "sideshow". 114

In the end, the Anglo-Saxon camp prevailed once and for all. Tim Krieger, holder of the Endowed Chair for Constitutional Political Economy and Competition Policy in Freiburg, commented: "[A]fter Cologne, it was clear to us younger economists that we would not be appointed professors if we worked on classical Ordnungsökonomik; that is why we oriented our work toward the international developments in the discipline from the beginning." 115

The fact that ordoliberalism still has considerable weight in some political and administration circles in Germany, however, could be recognized in two contributions to the dispute among economists. Then State Secretary in the Ministry for Economic Affairs Walther Otremba, who had prepared a doctorate on Barriers to Entry as a Problem of Competition Policy in Cologne in the 1970s, warned of overly strong mathematisation resulting from the planned reorientation of economics in Cologne, but admitted that "saying 'Freiburg School' in the morning and 'Ludwig Erhard' in the evening" would not suffice to keep up internationally. ${ }^{116}$ Weidmann, President of the Bundesbank, commented: "Personally, I couldn't and still can't glean much from this debate. Both are important; both complement each other: we need an economic policy framework founded on norms, that is, a guiding principle resting on proven principles." 117

\section{Ordoliberalism as political culture}

Jens Weidmann has mentioned Eucken in 33 of the 106 speeches he has given since becoming president of the Bundesbank in 2011. In a speech in Freiburg in 2013, he agreed with Lars Feld by repeating what

112 Ibid.

113 G. Kirchgässner, "Der Rückzug ins nationale Schneckenhaus”, Frankfurter Allgemeine Zeitung, 15 June 2009, available at: http://www.faz.net/aktuell/wirtschaft/wirtschaftswissen/oekonomenstreit-der-rueturfckzug-ins-nationale-schneckenhaus1811767.html, last accessed 22 August 2017.

114 Harald Uhlig quoted in O. Storbeck, "Deutsche Ökonomen zerfleischen sich", Handelsblatt 4 May 2009, available at: http://www.handelsblatt.com/politik/konjunktur/oekonomie/nachrichten/volkswirtschaftslehre-deutscheoekonomen-zerfleischen-sich/3169902.html, last accessed 22 August 2017; R. Bachmann, "Peinliche Unkenntnis", Handelsblatt 4 May 2009, available at: http://www.handelsblatt.com/politik/konjunktur/oekonomie/nachrichten/oekonomenstreit-ruediger-bachmann-peinlicheunkenntnis/3169652.html, last accessed 22 August 2017.

115 Interview with Tim Krieger on 30 May 2015. Despite the intractable positions, the dispute resulted in a partial renewal of the ordoliberal school. Feld proposed orienting classical ordoliberalism even more strongly toward the public choice school (L.P. Feld and E. Köhler, "Ist die Ordnungsökonomik zukunftsfähig?", (2011) 12 Zeitschrift für Wirtschafts- und Unternehmensethik, 173-195. Goldschmidt, Wegner, Wohlgemuth, and Zweynert sought to revive ordoliberalism's programme for society by developing it further in collaboration with North and Sen (Goldschmidt et al., "Was ist und was kann Ordnungsökonomik?", Frankfurter Allgemeine Zeitung , 19 June 2009). For the turn toward a "third generation" of ordoliberal thinkers recognized by the Walter-Eucken-Institut cf. V. Vanberg, Liberaler Evolutionismus oder vertragstheoretischer Konstitutionalismus? Zum Problem institutioneller Reformen bei F.A. von Hayek und J.M. Buchanan, (Mohr/Siebeck, 1982). For an authoritative elaboration, cf. L.P. Feld, "Eine Europäische Verfassung aus politökonomischer Sicht”, (2003) 54 ORDO: Jahrbuch für die Ordnung von Wirtschaft und Gesellschaft, $289-317$.

116 O. Storbeck, "Kölner Volkswirte bleiben hart”, Handelsblatt, 7 July 2009, available at: http://www.handelsblatt.com/politik/konjunktur/oekonomie/nachrichten/oekonomenstreit-koelner-volkswirte-bleibenhart-seite-2/3214752-2.html, last accessed 22 August 2017.

117 J. Weidmann, "Krisenmanagement und Ordnungspolitik", 2013, Walter Eucken Vorlesung on 11 February 2013 in Freiburg i.Br., available at: https://www.bundesbank.de/Redaktion/DE/Reden/2013/2013_02_11_weidmann.htm, last accessed 22 August 2017. 
Feld had stated in the Wirtschaftswochein 2011: he recommended that during the crisis, all politicians should put Eucken's "Grundsätze der Wirtschaftspolitik" ("Principles of Economic Policy") under their pillows. ${ }^{118}$ Nor can Chancellor Merkel escape the spell of Freiburg. She made a point of travelling to Freiburg on the occasion of Eucken's 125th birthday to declare her commitment to the principles of Ordnungspolitik. ${ }^{119}$

The most conspicuous is Finance Minister Schäuble, who emphasises his Freiburg origins time and again (in 18 of his speeches between 1 January 2010 and 1 December 2015), thereby referring not only to his place of birth and alma mater, but also to the fundamentally ordoliberal orientation of his policies as finance minister. Between 1 January 2010 and 1 December 2015, he discussed the ordoliberal concepts "Ordnungsrahmen" and "Ordnungspolitik" 36 times in the 80 speeches and interviews referring to German solidarity during the euro crisis. The deep Protestant grammar can also be found in Schäuble's argumentation. To Schäuble, the cause of the euro crisis is that some countries "lived far beyond their means until the crisis broke out", ${ }^{120}$ and that the countries of the South cannot demand unconditional solidarity since "the standard of living, the population's per capita income [...] was significantly lower in other euro area countries". ${ }^{121}$ The countries' behaviour had to change as a precondition for solidarity. Solidarity was not a "one-way street"; ${ }^{122}$ more "reliability" 123 and more "solidity" 124 was to be demanded of the crisis countries in return for solidarity. With these arguments, he takes up the Protestant core of empowerment which is embedded in ordoliberalism. Nonetheless, Schäuble appears unsure whether such appeals on moral grounds will be heard, "[f]or the terrible thing is: the fundamentals of human nature don't change". ${ }^{125}$ For that reason, the appeals to the debtor states'

118 Ibid. He became moralistic in a curious passage of a speech in Bremen. There, he described his admiration of the Prussian reformers, all of them reformed Protestants, and also the danger of exceedingly high sovereign debt by emphasising, "What the crisis has shown clearly, however, is that exceedingly high debt entails serious risks. Incidentally, Frederick III of Brandenburg was already aware of this. When he had himself crowned King Frederick I in Prussia in 1701, a general amnesty was announced from which only blasphemers, murderers, high traitors, and - debtors were excluded." J. Weidmann, "Stabiles Geld für Europa. Rede als Ehrengast bei der 470", Bremer Schaffermahlzeit in Bremen am 14. Februar 2014, available at: www.bundesbank.de/Redaktion/DE/Reden/2 014/2014_02_14_weidmann.html, last accessed on 22 August 2017.

119 A. Merkel, "Rede von Bundeskanzlerin Merkel beim Festakt zum 125. Geburtstag von Walter Eucken”, Freiburg, 13 January 2016, available at: https://www.bundesregierung.de/Content/DE/Rede/2016/01/2016-01-14-rede-waltereucken.html, last accessed 22 August 2017.

${ }^{120}$ W. Schäuble, "Farbe bekennen”, interview with Finance Minister Wolfgang Schäuble on German TV (ARD), 5 February 2015, available at: http://www.bundesfinanzministerium.de/Content/DE/Interviews/2015/2015-02-05-ard-textfassung .html, last accessed 22 August 2017.

${ }^{121}$ Idem, "Griechenland war auf dem richtigen Weg", interview with ZDF Heute Journal, 17 February 2015, available at: http://www.bundesfinanzministerium.de/Content/DE/Interviews/2015/2015-02-17-heute-journal-textfassung.html, last accessed 22 August 2017.

122 Idem, "Rede des Ministers Dr. Wolfgang Schäuble anlässlich des Neujahrsempfangs bei der Deutschen Börse AG”, 24 January 2011, Frankfurt am Main, available at:

http://www.bundesfinanzministerium.de/Content/DE/Reden/2011/2011-01-24-deutsche-boerse.html, last accessed 22 August 2017; idem, "Reform Der Europäischen Finanzregeln - Für eine bessere Verfassung Europas”, Berlin, 26 January 2011, available at: http://www.bundesfinanzministerium.de/Content/DE/Reden/2011/2011-01-26-humbold.html, last accessed 22 August 2017.

${ }^{123}$ Idem, "Rede von Dr. Wolfgang Schäuble anlässlich der Beratungen zum Europäischen Stabilisierungsmechanismus im Deutschen Bundestag", Rede in Berlin, 9 August 2015, available at: http://www.bundesfinanzministerium.de /Content/DE/Reden/2011/2011-09-08-rede-m-bundestag-zum-europaeischer-stabilisierungsmechanismus.html, last accessed 22 August 2017.

${ }^{124}$ Idem, "Griechenlands Reformen tragen erste Früchte", interview with Zeitung Ta Nea, 26 March 2013, available at: http://www.bundesfinanzministerium.de/Content/DE/Interviews/2013/2013-03-26-tanea-tageszeitung-griechenland-teil2.html, last accessed 22 August 2017.

125 Idem, "Berlin, Sicherheitspolitik im Spannungsfeld der Finanzen", Rede vom 24 June 2013, available at: http://www.bundesfinanzministerium.de/Content/DE/Reden/2013/2013-06-24-bundesakademie-fuersicherheitspolitik.html", last accessed 22 August 2017. 
moral obligation had to be accompanied by strong institutions strengthening ethically correct behaviour. This, again, is a Protestant-ordoliberal platitude. Since humans are simultaneously sinful and justified, institutions had to safeguard that their behaviour is just. Schäuble makes the functioning of the assistance dependent upon the correct "incentive systems". ${ }^{126}$ New institutions were to promote "helping the countries help themselves" (he refers to this in 11 of 80 speeches). ${ }^{127}$ To Schäuble, solidarity is necessarily linked to "conditionality" (he refers to this in 11 of 80 speeches), ${ }^{128}$ "consolidation" (he refers to this in 5 of his speeches), ${ }^{129}$ "discipline", 130 "sanctions", ${ }^{131}$ and "monitoring". ${ }^{132}$

Schäuble's calls for self-reliance, discipline, austerity, and modesty, which he seeks to stimulate by making moral appeals and institutional systems of incentives, are to be found not only in first-generation ordoliberalism, but also in the individual lay ethos of ascetic and pietistic Protestantism. ${ }^{133}$ In an interview with Der Spiegel, he emphasised, "My grandmother, who was from the Swabian Jura [translator's note: an area known for its traditional frugality], used to say: good-naturedness precedes licentiousness. There is a kind of generosity that can quickly produce the opposite of what is intended." 134 In 2015, he gave a speech at the German Protestant Kirchentag (Church Congress). He was asked to discuss a passage from the Gospel of Luke against the background of the crisis in Greece. The parable suggests, figuratively, that one can agree to debt relief in certain circumstances. Schäuble comments: "Hard to believe what we read here", and in his speech, he raises doubts about the accuracy of the Bible translation. He affirmed: "to forgive the debts someone has to another, and break the rules on your own authority: as a Christian, I cannot believe that Jesus recommends that we act in a way that would make it more difficult for people to live together, that would make life less safe, and that would make survival more laborious." 135 Then, he mentioned key values that are mentioned time and again in the first-generation ordoliberals' books: helping people help themselves, the danger of the wrong

${ }^{126}$ Idem, "Lebensversicherer müssen verstärkt Vorsorge betreiben", Rede in Berlin, 21 November 2013, available at: http://www.bundesfinanzministerium.de/Content/DE/Reden/2013/2013-11-22-gdv.html, last accessed 22 August 2017.

127 Idem, "Bankenunion macht Europa stabiler und handlungsfähiger", Rede in Berlin, 25 September 2014, available at: http://www.bundesfinanzministerium.de/Content/DE/Reden/2014/2014-09-25-Bundestag-Bankenunion-textfassung.html, last accessed 22 August 2017.

128 Idem, note 123 above.

${ }^{129}$ Idem, "Der Unbeugsame", interview in Focus, 7 May 2012, available at: http://www.wolfgang-schaeuble.de/derunbeugsame, last accessed 22 August 2017.

${ }^{130}$ Idem, “3. Lesung des Haushaltsgesetzes 2015 im Deutschen Bundestag”, Rede in Berlin, 25 November 2014, available at: http://www.bundesfinanzministerium.de/Content/DE/Reden/2014/2014-11-28-Bundestag-Abschluss-Bundeshaushalttextfassung.html, last accessed 22 August 2017.

${ }^{131}$ Idem, "Rede des Bundesfinanzministers zum Europäischen Stabilitätsmechanismus (ESM) und Ratifizierung des Fiskalvertrags", Rede in Berlin, 19 March 2012, available at: http://www.bundesfinanzministerium.de /Content/DE/Reden/2012/2012-03-29-rede-fiskalpakt-bundestag.html, last accessed 22 August 2017.

132 Idem, “Dr. Wolfgang Schäuble anlässlich der Verleihung des Grand Prix de l' Economie in Paris”, Rede in Paris, 12 January 2010, available at: http://www. bundesfinanzministerium.de/Content/DE/Reden/2010/2010-12-01-rede-grandprix.html, last accessed 22 August 2017; for the complete analysis, see J. Hien, "The Religious Foundations JCMSof the European Crisis”, (2017) 55 Journal of Common Market Studies: first view: DOI: 10.1111/jcms.12635.

133 S. Kahl, "The Religious Roots of Modern Poverty Policy: Catholic, Lutheran, and Reformed Protestant Traditions Compared", (2005) 46 Archives Européennes de Sociologie, 91-126, at 107.

134 W. Schäuble, "Der Bundesfinanzminister im Interview dem SPIEGEL vom 18. Juli 2015. Das Interview führten: Klaus Brinkbäumer, Michael Sauga und Christian Reiermann", 18 July 2015, available at: http://www.bundesfinanz ministerium.de/Content/DE/Interviews/2015/2015-07-20-spiegel.html, last accessed 22 August 2017.

135 Idem, "Bibelarbeit zum Evangelischen Kirchentag 2015 - Klug handeln - mit Q6 dem Mammon?, Rede in Stuttgart am 4. Juni 2015", available at: http://www.bundesfinanzministerium.de/Content/DE/Reden/2015/2015-06-04-kirchentag.html, last accessed 22 August 2017; see, also, D. Kirsten, "Schäuble legt die Bibel aus", 4 June 2015, Deutschlandfunk, available: http://www.deutschlandfunkkultur.de/bundesminister-beim-kirchentag-schaeuble-legt-die-bibelaus.2165.de.html?dram:article_id=321733, last accessed 22 August 2017, and J. Rahtz, "The Soul of the Eurozone", (2017) 104 New Left Review, 107-131. 
incentives, the advantages of frugality and of sustainable finances. He closed his speech with a reference to the original connection between ordoliberalism and Protestantism, referring to Dietrich Bonhöffer.

The rationales used by leading German politicians are steeped in references to the Freiburg School and commitments to ordoliberalism. The discourse, however, is oriented more toward the general ordoliberal patterns and platitudes rather than referring to deeper levels of ordoliberal theory. It was especially the fusing of elements of ordoliberal economic theory and normative Protestant platitudes that makes the political discourse by politicians such as Schäuble so appealing to German voters. So it is not only a discourse about virtues, but a reference to the original underlying values that were built into the theory by ordoliberals in the 1930s and 1940s. Alongside the beguiling concepts of the social market economy and the economic miracle of the 1950s, the ordoliberalism of the Freiburg School has become a landmark in German collective memory. This is, however, a highly superficial adaptation of ordoliberalism lacking greater theoretical potency, but with considerable acceptance in the German electorate.

\section{Conclusion}

Legal scholars, the protagonists of ordoliberalism, have had to realize that its notions of a law of an economic constitution and a legally stipulated economic policy have failed. ${ }^{136}$ Ordoliberal positions have also been pushed to the sidelines in German economic science. What has been retained is common beliefs that even extend into the communication of German policy-makers. But neither in law nor in economics are authors to be found who represent a genuinely ordoliberal approach to overcoming the crisis. What remains is a popular ordoliberalism, an ordoliberalism of the people, which the German political community uses to give reasons for the crisis and rationalize tough measures while drawing on ordoliberal platitudes of the 1950s and arguments appealing to underlying Protestant values. American commentators have described all this as a "moral lesson" 137 that divides the members of the European Union into "northern saints and southern sinners" 138 during the crisis. It is the deep ordoliberal-Protestant grammar which Anglo-Saxon and southern European observers perceive in admonitions made by German politicians' admonitions.

\footnotetext{
136 The most recent pertinent work on ordoliberalism we have been made aware of by Brigitte Young is an online publication "Ordliberalism: A German Oddity?", edited by Th. Beck and H. Kotz (CEPR Press, 2017), available at: www.cepr.org. Among the 20 contributors there is just one with some previous legal affinities (Philipp Steinberg). We conclude thatt we were well advised entitle our own work to which we have referred repetedly in the is essay Ordoliberalism, Law and the Rulke of Economics (Hart Publishing, 2017).

${ }^{137}$ M. Fourcade, “The Economy as Morality Play, and Implications for the Eurozone Crisis”, (2013) 11 Socio-Economic Review, 620-27.

${ }^{138}$ M. Matthijs, "Powerful Rules Governing the Euro: The Perverse Logic of German Ideas", (2016) 23 Journal of European Public Policy, 375-391, at 376.
} 

